\title{
SOB O SIGNO DE OTELO: FRANCISCO JOSÉ VIVEIROS DE CASTRO E AS “CONTRADIÇÕES” NA JURISPRUDÊNCIA SOBRE CRIMES PASSIONAIS
}

\author{
Carlos Martins Junior \\ Mestre pelo DH.FFLCH/USP
}

RESUMO: Baseado na análise da jurisprudência sobre crimes sexuais criada por Francisco José Viveiros de Castro no final do século XIX, este artigo estuda os critérios que a Justiça da época começava a usar para definir quem seria merecedor de sua "proteção" e os que cstariam excluídos dela. Com isso, fica-se diante do papel- representado pelo Direito no processo de submissão política c econômica dos indivíduos oriundos dos segmentos pobre e trabalhador da populaçāo - processo delinido, no plano semântico, pelo termo "civilizaçāo -, no período em que se instituía, no país, uma sociedade de classes nos moldes capitalistas.

\begin{abstract}
Based on the analysis of the jurisprudence on sexual crimes instituted by Francisco Viveiros de Castro at the end of the 19th century, this article studies the criteria that the judiciary began using to define those worthy of their "protection" as well as those to be excluded from it. Herewith, the law exercises a distinct role in the process - defined semantically by the word "civilization" - of political and economic submission of the citizens who belonged to the poor and hard-working segments of society during a period when a class system within capitalist structures is established in Brazil.
\end{abstract}

PALAVRAS.CHAVE: jurisprudência, cidadania, cxclusāo, criminalidade, sexualidade

KEYWORDS: jurisprudence, citizenship, cxclusion, criminality, sexuality

Na segunda metade do sćculo XIX, o Brasil passou por transformaçôes estruturais que se refletiam na própria paisagem urbana. A progressiva substituição da mão-de-obra escravista pclo trabalho livre assalariado, o surgimento das fábricas, o desenvolvimento dos sistemas de transportes e circulação de mercadorias, além do crescimento demográfico, acentuado pela chegada de levas de imigrantes europeus e pela incorporação à população urbana de elementos étnicos nacionais provenientes das áreas rurais, fizeram com que, no decorrer das três últimas décadas do século, cidades como Rio de Janeiro e 
São Paulo perdessem, aos poucos, o caráter provinciano e colonial.

A diversificaçāo das atividades cconômicas somada à maior complexidade das estruturas sociais tornavam o meio urbano cada dia mais desconhecido e assustador. Transformando as cidades $\mathrm{em}$ verdadeiros laboratórios de observaçāo, políticos c reformadores sociais construíram em relaçāo a elas imagens cxtremamente contraditórias. De um lado, as melhorias materiais como a construção e a remodelação de ruas e avenidas, a instalação de novos sistemas de saneamento $\mathrm{c}$ iluminação, bem como a busca de novas formas de lazer e prazer, denotavam a reprodução, aqui, dos padröes de comportamento europeus, determinando representaçōes do cspaço urbano como emblema da modernidade e do progresso. Por outro lado, o crescimento demográfico e físico em direçāo aos subúrbios, as agitaçōes operárias, a concentração da pobreza e a exposição pública do trabalho sustentavam, no plano das mentalidades. imagens das cidades como símbolos do caos, locais de concentração de uma multidão miserável e indisciplinada, a esconder em suas entranhas o crime, o vício e a doença.

Associada à visão da pobreza nas ruas, a multidão, sinônimo de ameaça política e de contágio moral, incutia nas mentes pensantes a preocupaçāo com o surgimento de uma onda de crimes contra a pessoa e a propriedade, imaginário amplamente alimentado pela imprensa sensacionalista emergente. As sensações de medo, espanto e indignação geradas pelo receio de contato com a "miséria abundante e hedionda", aliadas à correlação que se estabelecia entre crescimento urbano, pobreza, doença e criminalidade, reforçavam a idéia de que nas cidades o homem cairia na degenerescência física e moral. Tendo o darwinismo social c o positivismo como cobertura teórica, essa visão promoveu o desejo de se aprofundar estratégias de controle dos populares, de modo a garantir um crescimento ur- bano mais ordenado. Nesse contexto, processou-se a difusão de saberes que conduziram ao refinamento dos mecanismos de controle social, cristalizados, por exemplo, na mudança das concepçōes e práticas da saúde e na inflexāo da noção e da abrangência da criminalidade. Os diferentes "desvios" passaram a ser crescentemente separados c classificados, e para cada um dcles desenvolveram-se formas específicas de enfrentamento, respaldadas pela crença na ciência como fundamento do progresso.

Nascido da conjuntura que seguiu a abolição da escravidāo, tendo como prioridade a organizaçăo do mercado de trabalho assalariado e a integração do liberto a uma socicdade que começava a se autoconceber como uma comunidade de trabalhadores, coube ao regime republicano o aprofundamento da ideologia valorizativa do trabalho $\mathrm{c}$ de cstratégias de controle - dircto $\mathrm{c}$ indireto - das camadas populares. Pode-se dizer que, ao colocar a questão da disciplinarização dos indivíduos pertencentes aos segmentos pobre e trabalhador da população no centro de scu projeto político, os dirigentes republicanos não pouparam esforços para fazer com que os elementos ligados as chamadas "classes perigosas" assumissem em definitivo suas responsabilidades como trabalhadores e seus papéis sociais de pais e mães de família exemplares, pois da absorçāo do sentimento de "annor ao trabalho" $c$ do respeito aos valores de família (instituição apontada como a célula mater da sociedade) consolidava-se, aos olhos das elites nacionais, a imagem do "bom cidadão".

Dentre os vários instrumentos que os dirigentes republicanos lançaram mão para viabilizar a submis. são política e econômica do trabalhador, o aparclho jurídico foi um dos mais importantes. Como outros campos do saber, o Direito teve como meta a formaçāo c a administração política da população, num esforço de reelaboraçāo da classe trabalhadora de modo a possibilitar o aumento da riqueza e garantir os objetivos republicanos de "ordem c progresso". 
Influenciados pela cadeia perversão-hereditariedade-degenerescência criada pela Medicina, para os juristas brasileiros do final do século XIX e início do $\mathrm{XX}$ que partilhavam das teses da chamada nova escola penal de caráter positivista a desordem social verificada no país teria origem na constituição anômala do homem, que necessitaria de intervenção normalizadora. Para essa veriente do pensamento jurídico, caberia ao Poder Judiciário levar adiante uma açāo "civilizatória" visando ao estabelecimento da ordem sexual e da organização familiar, critérios básicos para a melhoria das futuras gerações e para a construção das bases daquela que era vista como a maior riqueza do Estado: a qualidade da população. Portanto, o sexo enquanto instituição $e$ a sexualidade cnquanto vivência transformavam-se definitivamente $\mathrm{em}$ assunto de interesse social.

À medida que o sexo ia sendo figurado como simbolização do bem e do mal c que sc percebia que este constituía um clemento fundamental para que o ideal disciplinar pudesse gerir politicamente o corpo, a vida e a proliferação, crescia o interesse pelo estudo dos crimes sexuais. Dentre os juristas que se dedicaram ao assunto, Francisco José Viveiros de Castro foi o mais destacado, por ter sido o primeiro a centrar a atençāo sobre esse tipo de delito, aprofundando conceitos e dando forma a procedimentos que pcrmitissem a melhor maneira de tratá-lo.

Introdutor no Brasil de um saber médico-jurídico que deveria penctrar todas as instâncias humanas, reconhecendo e opondo condutas "sadias" $\mathrm{e}$ "patológicas", os estudos desse jurista revelam a inquietação das autoridades públicas e dos intelectuais com a ameaça da "anarquia" das raças, das classes e dos sexos, pulsante na multidão urbana composta por trabalhadores, "vagabundos" e mendigos - na grande maioria negros e mestiços -, bcm como com os caminhos para ordenar seus comportamentos de acordo com as exigências impostas pela sociedade burguesa em implantação no país.
Defensor intransigente das concepçōes lombrosianas sobre a natureza do homem criminoso, Castro esforçou-se, de um lado, em difundir e explicar as bases teóricas em que se assentava o Direito positivista. Por outro lado, ao reforçar o nexo entre crime e comportamento individual e apontar os delitos sexuais como produto da dissolução dos costumes que ameaçava sobretudo a família de desagregaçāo, focalizou o interesse no aprofundamento de conceitos sobre as "patologias do instinto sexual" e sobre os crimes praticados contra a honra das mulheres, no intuito de orientar a magistratura quanto à melhor forma de coibir e punir todos os delitos de sexo. Mais do que a preocupação restrita à exclusiva aplicnção da lei, esse jurista manifestava a intençāo de criála, recriá-la e, se necessário, modificá-la para que fosse possível a atuação normalizadora da Justiça tanto em campos específicos, como a determinação da paternidade duvidosa, quanto nos de alcance social mais amplo, caso da organização do casamento civil e da família monogâmica. Daí seus textos deixarem transparecer um verdadeiro projeto civilizatório, voltado principalmente para as camadas sociais menos favorecidas, no interior do qual se espelhava uma proposta moralizadora condizente com as aspiraçōes das elites dominantes.

Exatamente por fornecer os subsĩdios necessários para que se possa penetrar, tanto no universo de idéias e mitos que dirigiram o debate em torno da reformulação da ciência jurídica nacional, quanto no simbólico que deveria reger a atuação dos agentes aplicadores da lei nos julgamentos de delitos sexuais, os trabalhos de Viveiros de Castro ganham destaque como fonte documental para o estudo do papel representado pela Justiça na questão da fiscalização do comportamento dos populares e do controle social quando da implantação e consolidação da República no Brasil.

Mesmo reconhecendo que a jurisprudência nāo tem necessariamente valor normativo (sabe-se que 
muitas decisões acatadas $\mathrm{em}$ Tribunal não raro the são diametralmente opostas), a opção em abordá-la parte do pressuposto de que nela as imagens formuladas a respeito das vítimas, acusados e testemunhas, a indicação dos procedimentos "técnicos" e dos caminhos a serem percorridos pelos "atores jurídicos" e pelos agentes julgadores balizam-se e são respaldados, em geral, num conjunto de normas e valores morais que num determinado momento histórico estāo incorporados aos traços de cultura de um grupo ou classe social. Valores que deverão ser incorporados pelos demais agentes sociais, ainda que seus códigos culturais, construídos e constantemente recriados e adaptados a novas situações sociais, os obrigue a transgredir alguma conduta moral que a Justiça pretenda impor como única realmente válida. Assim, a leitura desse tipo de fonte é útil em vários aspectos fundamentais para a formulaçăo dos objetivos propostos neste texto. Sob o ponto de vista geral, contribui para que se possa compreender a maneira como ocorria a constituição social dos papéis sexuais na medida em que se instituía no país uma sociedade de classes nos moldes efetivamente capitalistas e cm que, ao menos em test. todos começavam a ser vistos como iguais perante a lei - fato que precisava ser enfrentado da forma mais coerente possível, numa sociedade marcada por profundas desigualdades dos mais diversos matizes, desde as sociais até as sexuais e raciais. Além disso, permite maior percepção de um dos mecanismos de mediação através do qual a ordenação daqueles papéis deveria ser mantida e perpetuada, funcionando decisivamente para a manutenção das desigualdades o Judiciário. Do ponto de vista mais específico, se de um lado a jurisprudência reflete um projeto político de submissão dos trabalhadores, de outro, ao emitir opiniōcs e conceitos negativos - dominantes no universo mental das elites - a respeito do comportamento total em sociedade desses agentes sociais, acaba possibilitando a recuperação de aspectos importantes de sua organização cotidiana no tocante ao amor, à moradia, ao lazer e ao trabalho.

Livro precursor da literatura jurídica sobre as "aberraçōes do instinto sexual". Atentados ao Pudor compỏe, juntamente com A Nova Escola Penal e Delitos Contra a Honra da Mulher, a trilogia que sintetiza toda a teoria de Viveiros de Castro. Ncle, o autor dedica-se, primeiramentc, à "catalogaçāo cientificamente comentada" de todas as "expressões do instinto sexual" classificadas como "perversas" por Kraft-Ebing, por nāo corresponderem aos objetivos "naturais" da procriaçāo, tais como o onanismo, a sodomia e o homossexualismo, entre outras. E aqui Castro já se mostrava um inovador não só por criminalizar comportamentos e práticas sexuais que a Medicina brasileira havia considerado pervertidas. situando-as, porém, no terreno exclusivo da sexualidade doentia e da prostituição, mas, acima de tudo, por incorporar ao campo das patologias sexuais os chamados criminosos da paixão, a exemplo dos suicidas, ciumentos e assassinos. Sobre isso escreveu: “(...) pareceu-me que assim procedendo não alarguei demasiadamente os limites do quadro. Estes atos sāo também um desvio do amor natural, uma aberraçāo mórbida c têm a mesma etiologia, a degenerescência hereditária ou adquirida. Ramos da mesma árvore, não quis decepá-los" (CASTRO, 1934, p. VIII). A seguir, procurou estabelecer uma "etiologia do mal", encerrando o trabalho com a análise do papel da Justiça no enfrentamento de casos dessa natureza.

Fiel aos postulados da antropologia criminal italiana que identificava nos fatores biológicos a origem da criminalidade, Castro elegeu a hereditariedade como a principal razão dos "desvios sexuais". Advertia, contudo, que, cmbora as "nevroses" fossem, em geral, transmitidas hereditariamente, nem sempre assumiam os sintomas revelados pelo transmissor, podendo, ao contrário, aparecer em diferentcs variedades. Assim, um epiléptico poderia "gerar um criminoso", do mesmo modo que "um alcoóla- 
tra poderia gerar um ciumento", pois o que havia em comum era "o fundo da degenerescência, o desequilíbrio mental e nervoso" (CASTRO, 1934, p. 279).

Em concordância com Comte, afirmava haver no homem dois instintos básicos, "primeiros na ordem do aparecimento e ainda hoje os que mais fortemente influenciam na conduta": o "nutritivo", que the garantiria a existência, e o sexual, responsável pela reprodução da espécic. A humanidade seria feliz se tais instintos funcionassem harmoniosamente. Entretanto, longe desse ponto ideal, o que se verificava naquele final de século era um quadro sombrio, caracterizado pelo desenvolvimento das "aberraçōes sexuais" que, juntamente com o aumento do consumo de álcool, dos casos de suicídio, de loucura e das "nevroses em suas inúmeras manifestaçōes", afetavam não só a "vida, a honra $\mathrm{c}$ a liberdade de suas infelizes vílimas, como comprometiam a segurança social". Prova do aumento assustador dessas "aberraçōes", e ao mesmo tempo fato negativo a ser constatado, eram os jornais que todos os dias noticiavam atos contra o pudor, contribuindo para levantar o sentimento de indignação da opinião pública contra seus autores, a ponto de cristalizar um juízo contrário a eles, resistente mesmo a todos os argumentos $\mathrm{e}$ provas a seu favor. A partir daí, "a justiça os pune, a sociedade os estigmatiza e eles têm para sempre gravada cm sua vida a terrível sentença do inferno dantesco" (CASTRO, 1934, p. VI).

Para que a Justiça decidisse de modo imparcial. tornara-se imperioso reagir contra esse poderoso esquema de formação de opiniōes que, perigosamente, estenơia-se também aos magistrados. Propunha Castro, cntāo, medidas que iam da imposição de limites à atuação da imprensa, até a implementaçāo do método científico para promover a mediação entre a severidade da lei e a censura da opiniāo pública. Somente a ciência, em sua completa neutralidade, seria capaz de reconhecer se perante o Tribunal encontrava-se "uma alma corrompida, um per- verso a punir", ou se o ato praticado era "uma manifestaçāo da degenerescência mental ou nervosa, um impulso irresistível da vontade sem energia e sem centros inibitórios" (CASTRO, 1934, p. VI).

Eis aí como o autor de Atentados ao Pudor justificava seu interesse em tratar de assunto que, pessoalmente, admitia, pudesse provocar " $\mathrm{cm}$ toda alma delicada um natural sentimento de repulsa". Justificativas à parte, foi a exigência de normalidade, "superando repugnâncias e preconceitos", que o estimuJou a enveredar por terreno ainda não desbravado pelo Direito Penal brasileiro. Preocupado com a sexualidade, o jurista teve de "falar de sexo publicamente (...) como coisa que não se deve simplesmente tolerar, mas gerir, inserir em sistemas de utilidade, regular para o bem de todos segundo um padrão ótimo" (FOUCAULT, 1980, p. 27).

Definindo o livro como uma vulgarização das leituras dos mais avançados tratados científicos da época sobre as psicopatologias do instinto sexual, em Atentados ao Pudor Castro pretendia chamar a atenção dos magistrados e de todos os cstudiosos dos problemas penais sobre a situaçāo dos que compareciam à barra dos tribunais acusados da prática de crimes hediondos, quando, no mais das vezes, eram "vítimas de um estado nevropatológico". Negando que advogasse a impunidade daqueles que comprovadamente agiam sob "impulso de uma nevrose", sua intenção era, de um lado, demonstrar a irresponsabilidade dos mesmos perante seus atos e, de outro, salientar que deveriam ser tratados c não punidos, ser internados como doentes e não encarcerados como criminosos, haja vista que: "Há o crime c há a perversão. Há o criminoso e há o degenerado. $O$ primeiro deve ser punido, o segundo é irresponsável. O papel da justiça, portanto, deve ser a investigaçāo minuciosa do estado mental do acusado" (CASTRO, 1934, p. 297). Alicerçado na premissa de que "no cstado presente" da ciência penal brasileira os juízes ainda eram incompetentes para decidir so- 
bre tais questões, recomendava que o primeiro dever do magistrado - imposto pelas exigências da Justiça, da sociedadc e de "interesses respeitáveis da família" - era requerer o exame médico-legal do acusado e proceder de acordo com as conclusōes dos peritos. Refutando a argumentaçāo dos que viam nessa invasão dos tribunais pela Medicina a ameaça da magistratura se converter em mera rubricadora de sentenças determinadas pelos peritos, os quais se transformariam nos verdadeiros árbitros da repressão, chegava mesmo a ser contundente: "A missão da justiça não é condenar a torto e a direito e sim punir criminosos e absolver inocentes. Se a ciência nos ensina que a degenerescência mental produz aberraçōes sexuais, se tais degenerados não têm ou consciência de seus atos ou vontade para resistir aos impulsos, é de rigoroso dever apurar a condiçīo fisica e mental do acusado. E quem mais competente para esse exame do que o médico especialista, que tem experiência e prática nesses assuntos, que pode descobrir as simulações mais engenhosas? Ninguém se rebaixa confiando as autoridades competentes a decisão das questões técnicas. Só os ignorantes se atrevem a julgar sobre coisas que não entendem" (CASTRO, 1934, pp. 297-298).

Apoiado na tese de que em casos de atentados ao pudor estavam em jogo tanto interesses individuais (como a liberdade e a honra do acusado e a situação de sua família) quanto coletivos (especificamente a segurança social a ser acautelada contra "impulsivos perigosos"), ambos igualmente importantes, entendia o jurista desprovida de valor a altercaçāo dos adversários do Direito positivista de que, ao se isentar de responsabilidade os degenerados, se comprometia a segurança social pela impunidade do crime. Do seu ponto de vista, dado que para a nova escola penal o fundamento da pena era a defesa social ameaçada pela "temerabilidade" do delinqüente, a segurança pública ficaria imediatamente resguardada afastando-se o indivíduo do seio da sociedade, tão logo se revelasse sua periculosidade, fosse um criminoso ou um louco. De qualquer forma, "reconhecido seu caráter impulsivo, o juiz manda recolhê-lo ao asilo de alienados. A sociedade, pois, não corre o menor risco com a admissão dessa teoria" (CASTRO, 1934, p. 298). Nessa linha de raciocínio, os interesses individuais também seriam preservados. Condenado como criminoso, o degencrado tcria de cumprir pena sob regime "debilitante e exaustivo", em prisão celular. Sem tratamento algum, a punição cm nada contribuiria para regenerá-lo, servindo apenas para agravar ainda mais seu estado físico e mental. Porém, recolhido ao manicômio, colocado sob "tratamento conveniente", teria mais chances de se recuperar, transformando-se num cidadão "útil à sociedade". Mais que isso, levando-se cm consideração que a condenação - importando, no limite, no reconhecimento do caráter - não feria apenas o acusado individualmente, estendendo os efeitos inclusive a sua família, a qual passaria a "sofrer na consideração pública e na estima dos amigos", o reconhecimento da "loucura" serviria para "atenuar todos os inconvenientes" surgidos no cotidiano de quem tivesse "o nome manchado por uma condenação judiciária", pois já não se trataria mais de um "malvado e sim de um estado patológico que poderia acometer qualquer pessoa"; e "de médico, poeta y loco, todos tenemos un poco" (CASTRO, 1934, p. 299).

Se no plano ideologico essa proposta, qualificada pelo autor como "humanitária", visava a conferir maior equilíbrio entre o delito e a aplicaçāo da pena, na prática permitia, com a ajuda da ciência, o reforço de todas as hierarquias e desigualdades com as quais o Direito clássico já trabalhava. Hierarquias e desigualdades que operavam nos níveis sexualsocial - em que homens e mulheres recebiam tratamento diferenciado em função dos papéis que deles eram esperados, simplesmente por serem homens e mulheres - e social-sexual - no qual indivíduos de uma classe terão privilćgio de tratamẹnto, devido a 
sua inserção em determinada faixa da estrutura social. Isso fica claro na análise que Viveiros de Castro fez de dois assassinatos de mulheres ocorridos na segunda metade do século XIX, anıbos paradigmáticos para os cstudantes de Direito da época não só devido à posiçāo social de scus protagonistas, mas também porque, de acordo com os pressupostos do Direito científico, a Justiça tcria incorrido cm "erro". Trata-se dos casos José da Silva Mariano e Pontes Visgueiro.

A 6 de novembro de 1866, o médico José da Silva Mariano compareceu espontaneamente ao quartel do corpo policial do Rio de Janciro, confessando que na tarde daquele dia matara, a golpes de bisturi. sua mulher, Helena Augusia da Silva.

No depoimento, declarou que nos 19 anos em que fora legalmentc casado com dona Helena, csta sempre se comportara como uma senhora de conduta irrepreensível. Porém, a 4 de novembro, os criados. entre eles a escrava de nome Espiridiana, preveniramno de que cla o traía com um vizinho, Raymundo Alves de Souza, que cm suas ausências entrava na casa pelo telhado. Perplexo c desorientado, procurou um amigo, o ienentc-coronel Duarte, a quem desabafou o problema.

Na manhã de 6 de novembro, o coronel Duarte conversou longamente com dona Helena. Às $\|$ horas, chamou o declarante ao quartel, dizendo-lhe estar convencido de sua inocência e de que as suspeitas eram infundadas, nĩo passando as denúncias de mentiras tramadas pelos escravos visando a algum fim ignóbil. Comunicou-the, ainda, que ficara combinado quc, para a dissipação de qualquer boato, o casal passaria alguns mescs em São Domingos e que, ao retornarem ao Rio, morariam em outra casa.

Afirmando que as impressōes do amigo the haviam recobrado a confiança, o doutor Mariano comunicou à mulher que estava de acordo com a decisão, acrescentando, ainda, sua disposição de vender todos os escravos, ao que dona Helena obscrvou não concordar com a venda de Espiridiana, por ser escrava de total confiança, estima e muito sua amiga. O marido perguntou-lhe, então, se devia acreditar $\mathrm{em}$ tudo o que dissesse Espiridiana, ao que, um tanto perturbada, sua mulher respondeu que sim, tornando-se, depois, bastante pensativa.

Novamente agitado, Mariano jantou e subiu ao segundo andar. Transposto o primeiro lance de escadas, parou para ouvir o que se passava na sala onde haviam ficado sua mulher e Espiridiana; ouvindo a csposa dizer à escrava: "Então nos perdeste? Foste contar a teu senhor", ao que aquela respondeu: "Então meu senhor the disse?". O doutor Mariano desceu e perguntou a ambas o que havia, o que sabiam, ao que dona Helena respondeu "nada". Para evitar escândalo diante dos escravos, convidou a esposa $\mathrm{e}$ Espiridiana a subirem, interrogando esta última sobre o que havia visto ou sabia e se alguém havia entrado na casa. Simultaneamente, dona Helena, bastante perturbada, acenava com o dedo para que a escrava nada falasse, ao mesmo tempo $\mathrm{cm}$ que procurava afastá-la para o andar de baixo. Dizendo-se finalmente convencido da culpabilidade da mulher, Mariano apanhou um bisturi na cartcira de instrumentos cirúrgicos $\mathrm{c}$, depois de uma luta, fez em dona Helena os ferimentos fatais. Concretizado o crime, mandou chamar seu cunhado, o doutor Torres Homem, entregando-lhe a administração da casa c dos negócios, dirigindo-se, enfim, à delegacia.

A 11 de novembro, uma junta médica, da qual fez parte o doutor Torres Homem, certificou que o indiciado estava em estado de alienação mental, devendo ser recolhido ao Hospício Pedro II para tratamento adequado. Em laudo médico datado de 26 de novembro, atestaram os médicos dessa instituição que o doutor Mariano lá chegara apresentando sintomas de "hiperemia cerebral", sendo "notável" o delírio acompanhado de agitação, exacerbada em horas indetcrminadas. Nessc estado, classificado de "mania aguda". teria permanecido até o dia $15 \mathrm{de}$ 
novembro, quando, em funçâo do tratamento empregado, cessaram a agitação periódica e os fenômenos de "hiperemia cercbral", estando "atualmente em completa integridade da razāo", o que podia ser observado pela coerência com que respondia às perguntas a ele dirigidas. Dois peritos nomeados pelo juiz de instrução confirmaram que, dado o grande "constrangimento moral" a que vinha sendo submetido, as "faculdade intelectuais" do acusado estavam "alteradas e pervertidas" antes do crime, não restando dúvidas de que na hora $\mathrm{em}$ que matara a esposa cstaria fora do "perfeito uso da razão" e que provavelmente continuara em "estado de delírio" depois do crime.

A peça de defesa claborada pelo doutor Bush Varella foi dividida $\mathrm{em}$ duas partes. Na primeira, procurava-se provar que dona Helena havia realmente cometido adultério e que, diante disso, o acusado teria direito de matá-la. Na segunda, tentava-se demonstrar, com base nos laudos médicos, a irresponsabilidade do réu, uma vez que agira em estado de "loucura transitória".

Em julgamento realizado a 15 de dezembro de 1866, o júri deliberou que o réu de fato es'nva "louco" no momento do crime, optando por sua absolvição.

Em tese, Mariano tinha tudo para ser classificado como um criminoso apaixonado", da maneira como foi definido por Enrico Ferri. Não possuía nenhum antecedente que pudesse manchar seu caráter e sua honra, tampouco referências a anomalias biológico-anatômicas. Agira tāo somente pressionado por forte impulso de uma "paixão irresistivel", isto é, a "defesa da honra", ofendida por suspcitas de que a mulher o traía. Com um bisturi, aplicarathe uma série de golpes e depois entregara-se cspontaneamente, confessando $\mathrm{c}$ descrevendo detalhadamente o crime.

Muito antes de Lombroso e Ferri terem exposto as teses fundamentais da nova escola penal sobre as causas da criminalidade e as características dos cri- minosos e de Viveiros de Castro definir o exame do cstado mental do acusado como primeiro dever do magistrado $\mathrm{cm}$ casos de crimes sexuais, o juiz de instrução encarregado do crime da rua dos Barbonos convocara dois peritos para examinarem o réu. Mas ainda assim essa absolviçāo constituiu, para Castro, um dos maiores escândalos cometidos pela Justiça brasileira. Para colocar em dúvida a decisão da Justiça, o jurista desafiava sua própria afirmação de que "só os ignorantes se atrevem a jułgar sobre coisas que nāo entendem", questionando justamente o que considerava o mais fundamental nesses casos: o ntestado médico-legal.

Do seu ponto de vista, Mariano nāo apresentava nenhum sintoma que justificasse a alegaçāo de "loucura transitória", tampouco motivo aparente que pudesse descaracterizar a imputaçāo de crime e caracterizar a necessidade de tratamento. Näo vivia cle na "tranqüilidade do lar"? Nõo exercia normalmente sua alividade de médico? Não fora ele mesmo quem declarara ao chefe de polícia que, nos anos de convivência com a esposa, esta fora merecedora de total confiança, nada tendo a registrar que a desqualificasse como "mulher honesta"? Somente depois da delação dos cscravos, "gente indignn de crédito, ainda mais por alguém esclarecido como o cloutor Mariano", é que a desconfiança de infidelidade "brotou c agitou seu cspírito". Mcsmo assim, tranqüilizou-se ao desabafar com um amigo, voltando a agitar-se com palavras que disse ter ouvido $\mathrm{c}$ que, afinal, deram-lhe a "certeza" da infidelidade de dona Hclena.

Todas as suas atitudes após o crime - o fato de ter encarregado o cunhado da administração dos negócios, a descrição detalhada do ocorrido e a exposiçāo das "provas" de infidelidade - scriam, para Castro, mostras de que o acusado mantivera-se sempre lúcido. Assim, se seu ato obedeceu a um motivo, "teve uma causa que o explica", essa causa certamente scria, para o jurista, a crença de que o ma- 
rido tem o direito de matar a esposa adúltera ou simplesmente por suspeitar de sua infidelidade. Tal certeza se consolidava a partir do que considerava fosse uma contradição da defesa: "Se o doutor Mariano compreendeu o alcance do ato de sua muther, se matou-a para lavar em sangue a nódoa do leito nupcial, então não tinha delírio, nāo era louco. Mas se praticou o crime como louco, não matou a muther como adúltera" (CASTRO, 1934, p. 301). Portanto, a "excitabilidade do sistema nervoso" constatada pelos médicos teria sido muito mais um efeito que a cena do crime produzira do que a causa última do ato. Sendo assim, a loucura de Mariano não passaria de uma fraude da defesa, que apenas o "degradou" ao invés de restituir-lhe a honra.

A mesma sorte não teve o desembargador José Cândido Pontes Visguciro, acusado, aos 62 anos de idade, de ter matado Maria da Conceição, conhecida em São Luiz do Maranhão, local onde ocorreu o crime, pela alcunha de Mariquinhas Devassa.

Em que pese os autos indicarem que o assassino agiu de forma fria e premeditada, da perspectiva de Viveiros de Castro essa condenação foi uma iniqüidade, podendo ser evitada se os responsáveis pelo inquérito requeressem o atestado médico-legal do réu, o que os levaria à conclusão de que cometera o "horrendo crime em estado de loucura". Para referendar sua análise, baseou-sc na peça de defesa montada pelo doutor Franklin Dória, para quem o ato de Visgueiro significou o ápice de um lento processo de degenerescência iniciado aos cinco anos de idade, quando um surto de febre tifóide teria provocado o "abalo cerebral" que o deixara praticamentc surdo. Em decorrência disso, passara o réu a cultivar um temperamento impulsivo, colérico, violento e irascível, que, aos poucos, Ihe dificultava a sociabilidade. Para agravar ainda mais o quadro degenerativo: "Sob as aparências de uma vida metódica, entregava-se a excessos alcólicos e venéreos, e quem conhece um pouco da psiquiatria sabe a força do âlcool e de Vênus na etiologia da loucura". Em virtude dessas "causas individuais", estaria o desembargador "predisposto a experimentar em toda a sua intensidade os efeitos de uma paixão violenta no dia em que esta lhe assaltasse o espírito" (CASTRO, 1934, p. 302).

De acordo com a defesa, o mal de que sofria não o impediu de completar os estudos acadêmicos e de se distinguir na vida pública como juiz de Direito da comarca de Maceió, deputado provincial em duas legislaturas por Alagoas e desembargador da Relação do Maranhão. Além do mais, sabia fazer-se estimado pelos que the eram próximos, tendo sempre se destacado como bom filho e bom pai (Visgueiro tinha uma filha ilegítima, de quem cuidou até casála com o desembargador Basílio Quaresma Torreāo). Em sociedade era grave e correto, mantendo-se sempre com a "dignidadc de um homem que se respeita e sabe prezar sua posição social".

Entretanto, mudou completamente ao se aproximar de "Mariquinhas". "Acanalhado", era visto ao seu lado pelas ruas mais movimentadas de São Luiz, acompanhando-a a tavernas e a locais freqüentados "por gente de ínfima classe e sem moralidade". Pagava-lhe a casa em que vivia com a mãe, dava-lhe roupas e jóias, chegando mesmo a the propor casamento: "A paixão por essa rapariga endiabrada, dominando-lhe a vontade na fascinação da idéia fixa, roendo-lhe o coração como uma úlcera, aparcceuThe no declinar da virilidade, época terrível e perigosa. Ela era moça, devassa, dominada exclusivamente pela cxcitação genital; cle, velho, gasto, quase impotente. Os hábitos de sua vida sofreram modificação tāo radical que atestam o desequilíbrio mental" (CASTRO, 1934, p. 302).

Maria da Conceição era figura conhecida em São Luiz. Branca, aparentando 15 ou 16 anos, "medianamente gorda" $e$ de "razoável beleza", segundo consta dos autos começara a vida mendigando pelas ruas da cidade, passando, posteriormente, a se prostituir, 
vendida pela própria mãe, com quem "dividia os lucros desse torpe comércio". Na visāo de Castro: "Se essa rapariga fosse mais inteligente e hábil, se pudesse formar projetos de vida que garantissem o futuro, teria conseguido facilmente de Visgueiro o casamento; e mais tarde, dissipadas as primeiras repugnâncias, entraria como uma senhora casada e respeitada nos primeiros salōes da sociedade. Tola, porém, analfabeta, incapaz de um pensamento sério, entregue completamente a uma existência de baixas devassidōes, odiava esse amante velho e surdo, e dele lembrava-se somente para a exploração de sua bolsa" (CASTRO, 1934, p. 130).

Em duas ocasiōes, no mínimo, Visgueiro a teria flagrado com outro homem. Em outubro de 1872, por ocasiāo da festa de Nossa Senhora dos Remédios, encontrou-a em "franco colóquio" com um oficial do exército, ao qual tentou agredir. Irritado com os "abusos" de Conceição, resolveu aplicar-lhe uma surra, encarregando para isso o tenente Feliciano Peralles Falcão, que. cmbora pago para "executar o serviço, jamais levou-o a cabo. Preocupados com suas atitudes, os familiares convenceram-no, no início de 1873, a viajar ao Piauí $\mathrm{cm}$ visit 7 a amigos. Retornando a Sâo Luiz a 30 de julho, logo nos primeiros dias de sua chegada, Visgueiro tomou algumas atitudes no mínimo estranhas: encomendou dois caixōes, um de madeira, que deveria ser encaixado a outro de zinco, comprou clorofórmio e uma peça de pano preto. Entretanto, suas relaçōes com Maria da Conceição mantiveram-se sem incidentes até o dia 10 de agosto, quando ocorreu aquela que seria a última cena de ciúmes. De acordo com a testemunha Ana Rosa Pereira, costureira e amiga de Mariquinhas, estando nesse dia "na porta de sua casa, à 1 hora da tarde, mais ou menos, foi surpreendida pelo desembargador que, dando um pulo sobre sua cabeça, entrou em casa, havendo apenas tempo para gritar avisando Maria da Conceição, que aí se achava com o estudante Joaquim Costa; o estudante correu para a varanda e cla meteu-se embaixo da cama, no quarto em que eslavam. O desembargador buscou o estudante. deu-lhe conselhos e mandou-o embora, dirigiu-se a Maria da Conceição, pediu-lhe que saísse de debaixo da cama por causa da umidade, mas ela, que estava nua, não acedeu ao pedido e o desembargador foi embora" (MORAES, 1934, pp. 29-30). Declarou a testemunha, ainda, que embora Visgueiro sempre andasse brigando com Conccição por ciúme, fazendo-lhe ameaças que nunca concretizava, pois essas brigas nunca excediam "um ou dois dias", a partir daí, porém. a moça ficara mais aprecnsiva que nunca.

Visguciro resolveu, então, dar, ele mesmo, um "susto" cm Conceição. Tentou atraí-la várias vezes a sua casa, ao que Mariquinhas se recusou até o dia $14 \mathrm{dc}$ agosto, quando para lá se dirigiu acompanha. da de uma comadre, Thereza de Jesus Lacerda. Depois de servi-las de doces, Visguciro mostrou desejo de ficar só com Conceição, insistindo para que subisse ao quarto sob pretexto de lhe dar um presente. Sempre desconfiada, Conceição puxava Thereza pelo vestido para que esta não a deixasse só, mas, diante da teimosia do desembargador, separaram-se, marcando um encontro para depois do jantar, ocasiāo em que Thercza passaria para buscá-la.

Assim que a moça entrou no quarto, um criado da casa, Guilhermino, com a cabeça coberta por um capuz preto, agarrou-a e o desembargador a fez des. maiar com uma toalha ensopada de cloroformio. De acordo com Guilhermino, antes de desmaiar, Conccição teria dito: "Meu amor, não me mates", ao que Visgueiro teria respondido: "Não te dizia sempre que havias de me pagar?". Em seguida, atirou-se sobre cla gritando: "Nāo te havia dito que te daria um co. nhecimento pelo pouco caso que de mim fazia com tcu amigo Joaquim?". Desferiu-Ihe vários golpes de punhal e. já morta, arrancou-lhe a dentadas um dos seios. A partir daí, esquartejou o corpo e depositou os restos nos dois caixōes que mandara preparar, 
colocando-os numa estante de livros na sala. Terminada a macabra operação, dirigiu-se a uma festa em casa de parentes, onde em momento algum manifestou qualquer abalo emocional que pudesse levantar suspeitas sobre o que fizera.

Sem contar a brutalidade que cercou os acontecimentos, o comportamento $\mathrm{e}$ as atitudes posteriores do assassino contribuíam, segundo Castro, para reforçar seu estado de insanidade mental. Homem inteligente e ilustrado, Visgueiro em primeiro lugar supôs, ingenuamente, que o cadáver se conservaria por um período de três meses, quando o levaria consigo numa viagem que pretendia fazer ao Piauí. Passados alguns dias, porém, os efeitos da putrefação convenceram-no do engano. Ao invés de lançar o caixāo ao mar, que dava fundos para a sua casa, fazendo com isso desaparecer a principal prova do crime, facilitou o trabalho da polícia, enterrando-o no jardim. Por outro lado, a calma demonstrada depois do assassinato $\mathrm{e}$ a impassibilidade que apresentou numa festa de família nada mais significariam do que a "sensação de alívio, de descarga elétrica que os loucos experimentam quando se libertam de uma idéia fixa que os tortura" (CASTRO. 1934, p. 303).

Só em aparência há conıradição na postura de Castro ao interpretar os dois casos. É que, apesar de fixar um argumento técnico - o atestado médico-legal - para colocar $\mathrm{em}$ dúvida a decisāo dos agentes julgadores, o jurista nāo conseguc esconder o critério tradicionalmente relevante em conflitos desse gênero: a adequação social das vítimas e dos réus. Dessa forma, sua abordagem deixa transparecer que, embora Mariano e Visgueiro rompessem a regra fundamental de nãomatar, erraram aqueles que os julgaram somente por essa atitude, pois o que deveria efetivamente determinar a opçāo do grupo julgador c a graduaçāo das penas era saber até que ponto acusados e vítimas haviam qucbrado outras normas sociais.

Fica-se, portanto, diante da quebra do mito da igualdade de todos perante a lei. Segundo Mariza
Corrêa, esse mito confronta-se consigo mesmo quando o debate jurídico permite a entrada da realidade concreta - esta mesma feita essencialmente de desigualdades -, o que fica claro quando os próprios "atores jurídicos", utilizando-se dos poderes que lhes confere a lei, procuram reforçar um ordenamento social preexistente, ao mesmo tempo em que se esforçam em obscurecê-lo, agindo como se ele nāo existisse - manipulação de que têm plena consciência que realizam permanentemente. É justamente em nome desse ordchamento social que Viveiros de Castro convoca para a discussão os dois crimes descritos. Na verdade, o que está em jogo em sua análise são os atributos com que os homens e as mulheres que os protagonizaram são apresentados e aceitos como adequados na relação que mantém um com o outro.

É preciso lembrar que, ao definir o casamento lcgal como único modclo social e moralmente aceito para a discussão do relacionamento entre os sexos, o jurista acaba aceitando também a identidade social de cada um deles, supostamente implícita nesse modelo, isto é, o homem como figura ativa $\mathrm{e}$ a mulher como ligura passiva. Assim, o aspecto mais enfatizado pelos agentes jurídicos brasileiros no caso da morte de um dos cônjuges ou companheiro por outro é o da relação homem-mulher a partir de elementos considerados necessários para que esse relacionamento seja aceito como "normal".

Estando os limites da mulher restritos ao âmbito do lar, é como esposa que cla será julgada. Portanto, caso se transforme $\mathrm{cm}$ vítima de um assassinato, a infidelidade transforma-se num ponto importante a ser explorado na argumentaçāo dos advogados. Manipulando o parâmetro casamento, no interior do qual a identidade feminina é definida a partir dos papéis sociais de mãe c esposa, a estratégia das defesas é a de deslocar a discussão para o que supostamente os jurados possam acreditar ser um motivo suficientemente forte para um "homem honrado" 
cometer um "ato impensado" - a infidelidade. A partir daí, passa-se a trabalhar com oposições abso. lutas, do interior das quais emergem imagens em que o acusado representa o bem c a vítima, o mal.

Dada a sua larga experiência como promotor público, advogado e juiz criminal, ninguém melhor do que o nosso jurista para reconhecer esse tipo de manipulação dos signos jurídicos. E ninguém meThor do que ele para reconhecer o perigo representado por esse tipo de manipulaçāo em determinados momentos, particularmente naquele em que se procurava regulamentar as relaçōes afetivo-sexuais através do casamento legal e em que a família era tomada como "alicerce de toda a ordem social". Por isso, no caso Mariano, pensando como promotor público - em geral mais severos com os assassinos de mulheres, em especial da própria esposa -, Castro considerava que, ao darem tanta relevância ao atestado médico, os jurados acabaram desprezando provas da inocência de dona Helena quanto à acusação de adultério que the fazia o marido. A começar pelo fato de que tal acusaçño não se bascava $\mathrm{cm}$ fatos concretos, principalmente por nāo se ter caracterizado o quadro de flagrante adultéric que configuraria, aos olhos da Justiça, a tese de legítima defesa da honra. Ao contrário, o quadro apresentado era o de um homem que apenas desconfiava da traição da esposa, que durante tanto tempo de convivência jamais dera provas de ser mulher sem honra. Acrescente-se a isso o fato de que, para a Justiça, uma convivência de mais de dez anos constituía tempo suficiente para que os laços entre o casal se estreitassem, permitindo ter maior clareza a respeito do caráter de cada um dos cônjuges. Mais ainda, mesmo que o flagrante adultério se configurasse, nem por isso o motivo do crime do doutor Mariano deveria ser considerado menos fútil, pois, da perspectiva de Castro, para um homem dotado de "inteligência e senso moral medianos", o adultério ou, o que é pior, a simples suspeita de infidelidade não deveriam ser, jamais, "motivos proporcionados para um delito de tamanha gravidade".

Defensor do divorcio e da eliminação do adultério como crime passível de punição pelo Código Penal, o que Viveiros de Castro questionava era o fato de que a "infidelidade conjugal" constituía a única falta punida com a pena de morte, imposta por um particular que aparecia ao mesmo tempo como juiz e algoz de sua vítima. Para ele, na alegação de legítima defesa da honra, justificada pcla perda momentânea dos "sentidos da razão", o que ocorria era o sacrilício de uma vida em nome de preconceitos que ainda existiam na socicdade, não passando cssa prática de uma tradição equivocada que sc tornara incompatível com os foros de civilizaçāo, uma vez que ninguém tinha o direito de responder com a morte a uma ofensa que the era dirigida, ainda mais quando a própria lci previa puniçōes para isso, reservando à mais culpada das mulheres uma parcela mínima de direitos. Em outros termos, esse tipo de alegação ou de qualquer outro artifício visando a legitimar o assassinato da esposa adúltera pelo marido, sob a justificativa de que assim não agindo correria o risco de ser desconsiderado no meio social, nāo passava de um ato de reminiscência bárbara a ser superada pela civilização. Por atentar contra os princípios civilizatórios, por não ter nenhuma proteção legal, esse tipo de ato resistia apenas $\mathrm{cm}$ função da benevolência de juízes e preconceitos dos jurados. E no caso Mariano, a atilude do réu tornava-sc ainda mais grave porque, por pura desconfiança, vingara-se em nome de um patrimônio - a honra - que jamais seria restituído com o derramamento de sangue.

Por tudo isso, entendia Castro que, absolvendo Mariano, a Justiça não só o degradou, como degradou a própria vítima, repudiando-a, não obstante a ausência de provas reais de adultério. Ademais, ao legitimar a atitude do acusado, os agentes julgadores teriam atentado tanto contra a própria Justiça, desni- 
velando os sexos perante a lei, quanto contra a instituição da família e do casamento.

Entretanto, o apelo à igualdade dos sexos perante a lei desaparcce na análise do "erro" cometido no caso Pontes Visgueiro. Aqui o discurso da defesa transforma-se em peça fundamental, porque reforça uma série de valores tidos como socialmente adequados, contrastando com a apresentação de uma personalidade apontada como defeituosa. $O$ pano de fundo da estratégia seguida pelo doutor Franklin Dória era estabclecer um claro contraste entre a conduta de seu cliente e a inadequaçāo social de Mariquinhas.

Considerada uma das mais brilhantes defesas de crimes passionais do final do século passado, a argumentação montada por Dória é, de ponta a ponta, um documento riquíssimo. Três anos antes de Lombroso publicar $O$ Homem Delinquiente c uma década antes de Ferri ter incluído $\mathrm{cm}$ sua classificaf̧āo dos criminosos a figura do criminoso passional, o futuro Barâo de Loreto refutava a prática das promotorias de enfatizar a calma revelada pelos assassinos como mais uma prova de que agiam dentro da normalidade psíquica e não sob influência de fatores patológicos ou passionais. Ao inverter cssc raciocínio, sua intenção era fazer com que aquilo que poderia ser utilizado de modo favorável pela promotoria se convertesse $\mathrm{cm}$ elemento plausível para que se alcgasse a irresponsabilidade criminal do acusado. Demonstrando grande habilidade, desprezou a tese da "loucura transitória", preferindo deter-se no estudo dos efcitos que a paixão poderia causar no ânimo de uma pessoa debilitada $\mathrm{e}$ idosa como seu clicntc.

Para reforçar a imagem de homem comum do réu, transformando-o, estralcgicamente, em pessoa suscetivel às mesmas emoçōes de outros homens (inclusive dos que o julgavam), Dória nāo escondia que, apesar de todas as qualidades, seu clientc não estava isento de defeitos; "mas", questionava. "qual o ser humano que normalmente não os possui"? Numa alusão ao fato de que a fidelidade não era atributo a ser relevado quando o sexo masculino estava em julgamento, apontava $o$ advogado que de todos os defeitos talvez o mais marcante fosse sua "inclinação para mulheres". Entretanto, sua virtude residia no fato de jamais ter "poluído o tálamo da esposa", nem "violado o leito da virgem". Sublinhava, entāo, que se Visgueiro tivesse encontrado o "verdadeiro amor", isto é, aquele que não se baseia apenas na sensualidade, mas sobre as "qualidades morais da pessoa amada" e que está pronto a todos os sacrifícios, o quadro degenerativo de que era portador poderia ser revertido. Não que seu constituinte se indispusesse a aceitar esse "amor sacrifício", afinal jamais recuara diante de qualquer dificuldade que se antepusera entre ele e Maria da Conceição. Não cra certo que para possuí-la cometera atos que, antes de desonrá-lo, deveriam ser vistos como provas de "heroísmo e destemor diante da morte", a cxemplo das vezes $\mathrm{cm}$ que investiu contra outros amantes da moça, muito mais jovens do que ele? Nĩo era certo, também, que perdera o respeito público ao se expor ao ridículo? Mais que isso, não era certo que, coerente com sua conduta moral e social, já sustentando Conceiçāo c sua mãe, tentou "regenerá-la" propondo-lhe casamento, sob a condiçāo de que se "resguardasse" por algum tempo? Proposta que ela, "mulher sem pudor", recusou, preferindo manter-se "infiel".

De acordo com essa linha de raciocínio, o destino conspirara contra Pontes Visgueiro ao ter colocado $\mathrm{cm}$ scu caminho uma mulher como Mariquinhas, cujo caráter estava muito distante do modelo de mulher "honesta". Mantendo-se sempre celibatário devido a uma decepção amorosa na juventude, sem encontrar uma "boa estrcla" que o empurrasse aos braços de uma "boa esposa". de uma mulher que the fossc amiga c conselheira, que o sustentasse nos desalentos e que até o "guiasse em seus desvios", 
inclinara-se o desembargador para várias paixões, entre elas aquela quc o levaria a "perder-se". Objetivando criar uma linha causal a partir da qual cssa relação só poderia chegar a um trágico desfecho, também os antecedentes morais e sociais da vítima foram evocados pela defesa, sem que nenhum detathe escapasse na configuração da imagem negativa daquela que deveria encarnar as qualificaçōes do vício c do mal.

Diferentemente de Visguciro, homem ilustrado e já equilibrado na vida, Conceição, oriunda de um "meio social viciado", ignorante, analfabeta e imprevidente, jamais conhecera uma lamília completa. Nada fora dito sobre scu pai, e a mãe era apontada como principal agente de sua "prostituição precoce". Aproveitando o testemunho de Ana Rosa Pereira de que quase todas as noites Mariquinhas dormin $\mathrm{em}$ casa do desembargador acompanhada de amigas, "pernoitando todos no mesmo quarto", sugeria o advogado que, por influĉncia da vítima, a casa de seu cliente passara a reproduzir as condiçōes dos cortiços. Além disso, o fato de o réu procurá-la a qualquer hora do dia ou da noite devia ser visto como comprovação do desleixo com que a mãe a tratava, reforçando a idćia de que Conccição não era vigiada, procedimento normal entre as famílias "honradas" $\mathrm{cm}$ relação às suas filhas. Enfïm, tudo concorria para definir e repisar a identidade civil da vítima como uma mulher "desonrada" e de "má fama".

1. Juridicamente, honra constitui a dignidade da pessoa que vive honestamente, ou scja, pautando seu procedimento pelos ditames da inoral. Ja fama, diz respeito à estima social de que determinada pessoa goza por conduzir-se de acordo com os "bons costumes". No caso da mulher. especialmente da jovem solteira. a virgindade é um importante indício da honestidade e recato. Cf, OLIVEIRA. J.L. de. Mamal de Direito de Familia.
Foi, portanto, a paixão não correspondida pela "infidelíssima" e "viciosa" Mariquinhas Devassa o que colocou um homem do caráter de Pontes Vis. gueiro sob a forte pressão psicológica que o fez co. meter não só os "atos indecorosos" contraditórios com a "prudência c o pudor" que lodos no Maranhão atć então the reconlieciam, como o hediondo crime pelo qual estava sendo julgado. Dessa forma, o desembargador era praticamente deslocado da posição de réu para a de vítima de Maria da Conccição. No limite, era cla quem deveria estar em julgamento. É como se Dória sugerisse que a opinião pública que o havia condenado aprioristicamente e todos os que haviam cercado e apedrejado sua casa $\mathrm{cm}$ São Luiz devessem pedir-the desculpas e render-lhe homenagens por ter arrancado do convívio social uma mulher "corrompida" de tamanha periculosidade.

Apesar dos esforços da defesa $\mathrm{cm}$ demonstrar que, não obstantc a barbaridade com que agira, o acusado nĩo demonstrava nenhuma periculosidade ou qualquer possibilidade de retornar ao banco dos réus, a 13 de maio de 1874 um júri togado conde. nou-o à pena máxima de prisão perpélua com trabaIhos forçados.

Ao condenar Visgueiro, a Justiça absolveu Conceição das acusações que lhe cram imputadas. Isso não quer dizer, porém, que deixasse de reconhecer que a imagem dela montada pela defesa fosse incorreta. Na realidade. quando os agentes julgadores se recusam a sancionar a violência masculina, cstão menos preocupados em se opor à noção de dominação da mulher pelo homem do que com a tentativa de controlá-la, isto é, de estabelecer limitcs no interior dos quais essa violência torna-se possível de ser praticada, bem como de buscar uma homogeneizaçāo dos motivos que justifiquem o repúdio da mulher (sua morte) e a accitaçāo da atitude masculina através da absolvição do acusado. Isso posto, é possível especular em torno dos motivos que fizcram com que Pontes Visgueiro losse condenado. 
Em primeiro lugar, pode-se dizer que, para os agentes julgadores, o ato do desembargador não possuía justificativa plausível, simplesmente porque Mariquinhas não era sua esposa. Dado que, à vista da Justiça, somente o casamento, definindo as atribuições dos cônjuges, delegaria ao homem o direito ao corpo, à vida e à morte da esposa, nenhum direito tinha o réu sobre a moça. Em segundo lugar, a tendência desse homem a se aproximar de mulheres "desonradas" e, no caso em questão, de uma mulher "comprovadamente" prostituída, talvez tenha sido percebida pelo jüri como uma demonstração de que, antes de doente, deveria ser o próprio Pontes Visgueiro um "viciado", representando, portanto, ele próprio, um perigo social. Nessa medida, como alto funcionário da Justiça do Império, fato que por si já deveria fazê-lo afastar-se de pessoas como Mariquinhas, a legitimação de seu ato colocaria sob suspeita a própria instituição a que servia. Assim, decidiuse que sobre ele deveria recair, ainda mais forte, $o$ peso da lei, que nāo só pune mas ensina. Ensina da mesma forma que o réu quis ensinar sua vítima quando, pretextando dar-Ihe uma "lição", afastou-a definitivamente da sociedade.

De todo modo, tudo leva a crer que, na interpretação daqueles que o julgaram, Pontes Visgueiro não entendeu com clareza as regras do jogo social: que a reação de um homem contra uma mulher que pen-: sa possuir, mas que sabidamente o trai, não pode ser um ato de puro delírio. Que mesmo para matar é necessário obedecer a alguns códigos, entre eles que o homem realmente possua a mulher - e o casamento tem aqui um peso decisivo. Enfim, que a exigência de um motivo plausível é esta: não basta apenas a alegação de uma traição para legitimar um assassinato, é preciso, antes de mais nada, que essa alegaçâo seja lida e aceita por todos os que devem julgálo. Nesse sentido, o que os agentes julgadores parecem ter dito com sua atitude é que, embora o desembargador até pudesse acreditar que era traído, $\mathrm{em}$ nenhum momento Mariquinhas, the fora infiel. Ela era, isto sim, uma "mulher pública" e como tal agia.

Mas há ainda uma outra hipótese para explicar o trágico destino de Maria da Conceição, a qual nem de longe foi aventada pelos "atores jurídicos".

Segundo algumas testemunhas, o primeiro contato entre o réu e a vítima teria ocorrido por volta de 1862 ou 1863, quando Mariquinhas aproximouse de Visgueiro pedindo-lhe esmolas. Por qualquer motivo que jamais será conhecido, este passou a ajudá-la com freqüência, transformando-se numa espécie de padrinho da casa.

Com o correr do tempo, porém, o desembargador pode ter começado a alimentar o desejo secreto de possuí-la. Sem nunca ter manifestado explicitamente esse intento, suas atitudes, acompanhando-a a festas e bailes populares, bem como as interdições que pretendia impor ao comportamento sexual da moça, talvez fossem lidas, por ela e a mãe, como produto de preocupaçōes paternas. Aliás, parecer ter sido muito mais como pai do que como amante que Visgueiro agiu quando, quatro dias antes do crime, flagrou Mariquinhas em casa de Ana Rosa com o estudante Joaquim Costa. No episódio, apenas repreendeu o rapaz e pediu à moça que saísse de debaixo da cama devido à umidade. Nas palavras de Ana Rosa, Visgueiro agira como sempre havia agido, isto $\hat{\epsilon}$, sem violência, pois, como atestava a testemunha, jamais o vira maltratar Maria da Conceição. O detalhe é que, somente a partir desse dia, o desembargador manifestou claramente suas intençōes, pedindo à moça que se casasse com ele. Pedido, como se sabe, por ela rejeitado. Diante dessa nova realidade, que tornara a menina arredia e a relação entre ambos insustentável, o desespero de Visgueiro deve ter crescido, a ponto de consolidar o desejo de vingar-se.

Interpretado pela defesa de modo a reafirmar a má índole de Conceiçāo, se lido nas entrelinhas o testemunho de Ana Rosa Pereira ć chave para a compreensão de alguns pontos importantes e obscuros 
nessa trama. Embora explicite que Mariquinhas era sexualmente ativa $\mathrm{e}$ que aceitava as benesses $\mathrm{c}$ os convites do desembargador para que comparecesse a sua casa a qualquer hora do dia ou da noite, a depoente deixa entrever que a vítima não manifestava nenhum interesse amoroso em relaçāo a ele. Isso se confirma na alegação da própria testcmunha de que, quando ia à casa de Pontes Visgueiro, Mariquinhas levava consigo companheiras que dormiam no mesmo quarto que ela e o desembargador. Se a defesa via nesse "amontoamento de corpos" um indício de promiscuidade semelhante ao que supostamente se verificava nos cortiços, o mesmo fato pode ser interpretado como uma forma de a moça se preservar diante de qualquer investida do réu. Aliás, o fato de estar constantemente acompanhada, por si já desmonta a hipótese de que Maria da Conceição era uma mulher "sem pudor". Destaquc-se, por exemplo, que na noite em que foi morta, já bastante ressabiada com as atitudes de Visgueiro, fez-se acompanhar a sua casa por uma comadre, a quem o réu praticamente expulsou de lá.

Tampouco a tesc de que a vítima não tinha família e não recebia cuidados da mãe resiste à análise mais cuidadosa de alguns depoimentos. Basta citar que, na noite do crime, preocupada com a demora da filha que ficara de se encontrar com a comadre por volta da hora do jantar, sua māe, acompanhada de um grupo de vizinhas e amigas da menina, foi esperá-la no portão da casa do desembargador, que ali as encontrou quando voltava da festa em que estivera. Argüido sobre o paradeiro de Mariquinhas, disse nada saber e que apenas cstivera com cla alguns minutos à tarde, quando the dera dinheiro para que comprasse umas fitas. Como se não bastasse a solidariedade dessas amigas, vizinhas e comadres, a propria conduta dos populares ao apedrejarem a casa de Visgueiro e a vigília permanente que realizaram em frente ao seu portão nos dias que sucederam o desaparecimento da moça, sugercm, no míni- mo, que a alcunha que the cra atribuída nāo vinha do segmento social ao qual ela pertencia.

Em suma, mulher do povo, cujas condutas eram regidas por outros códigos culturais, nada impedia que Conceição aceitasse a solidariedade e o apadrinhamento do desembargador, rejeitando, ao mesmo tempo, qualquer tipo de aproximação amorosa de sua parte, preferindo relacionar-se com homens mais jovens e de seu grupo social. Por não aceitar ou não se aperceber desse fato, Visguciro fê-la pagar e pagou, ele próprio, um preço caro.

Exatamente por não ter repudiado essa mulher, cujo comportamento social e moral, diferentemente do de dona Helena, deveria cstar aprioristicamente sob suspeita, é que, scgundo Viveiros de Castro, a Justiça errara. Se fosse reconhecida a insanidade mental, Pontes Visguciro seria encaminhado para tratamento médico e a falta cometida por um homem de "reconhecida posição na sociedade" teria sido atenuada. Dessa forma, a condenaçāo assumiria um caráter praticamente simbólico, não só pelos motivos já discutidos, mas também porque a internaçāo constituía, para indivíduos de certas camadas sociais, um privilégio, sc comparada com a vida nas prisōes, sem contar que o lugar ocupado pela pessoa na socicdade, bem como a influência exercida pela família, poderia determinar a consırução de laudos médicos favoráveis, abreviando a internaçīo. Contrariamente, ao enviá-lo para a prisão, não só o degradaram como "conspurcaram com a nódoa de um crime" toda a sua família. Dessa perspectiva tcórica, portanto, num momento $\mathrm{cm}$ que se procurava fazer com que o Dircito assumisse sua parte no processo de "civilização" dos popularcs, fazendo com que cada um reconhecesse seu lugar na socicdade, a puniçāo do desembargador atentara contra a própria ordem social.

Um ano e mcio depois da condenaçāo, Pontes Visguciro morreu na prisão, vítimal de um ataque cardíaco (o que, na visĩo de Castro, seria mais uma prova de seu estado de degenerescência). Durante mui- 
to tempo seu crime permaneceu na memória dos populares do Maranhāo e de diversas províncias do norte do país, gerando lendas e cordéis sobre cle c Maria da Conceição. Uma das coisas que mais alimentou a imaginação popular foi a incerteza quanto ao destino do criminoso. Uns nāo acreditavam em sua morte, preferindo pensar que isso servira de pretexto para acobertar o fato de que fora solto e se encontrava em Lisboa, onde muitos brasileiros afirmavam tê-lo visto e até lhe falado. Outros suspeitavam, apavorados, que um dia rctornaria a São Luiz em busca de vingança.

No imaginário das crianças, Visgueiro transformou-se numa espécie de "papão". Humberto de

\section{Bibliografia}

CAMPOS, Humberto de. Destines. Rio de Janeiro, Livraria José Olympio Edilora, 1935.

CASTRO, Francisco José Viveiros de. Alentados ao Pudor: Sobre as Aberraşäes do Instinmo Sextual. $3^{2}$ ediçāo. Rio de Janeiro, Freitas Bastos, 1934 ( $I^{2}$ cdição de 1895).

A Nowa Escola Peral. Rio de Janciro, Livraria Moderna, 1894.

Delitos Comtra a Honra da Mullie: $3^{2}$ edição. Rio de Janeiro. Freilas Bastos, 1932.

CHALHOUB. Sidncy. Trabalm. Lar e Botequim - O Conidiano do Trabahador no Rio de Janeiro da Belle Époque. São Paulo, Brasiliense, 1987.

CHAUí, Marilena. Repressāoo Sexual Essa Nossá (Des) Conhecida. São Paulo, Brasiliense, 1984.

CORREAA. Mariza. Morse em Familia: Representą̧ōes Juridicas dos Papéis Sexuais. Rio de Janeiro. Graal, 1983.

CUNHA, Maria Clementina Pereira. O Espelho do Mundo. Juquery, a Historia de um Asilo. Rio de Janeiro, Paz e Terra. 1986.

DARMON, Pierre. Mëdicos e Assassinos na Belle Époque. Rio de Janeiro. Paz e Terra, 1991.

DUARTE, Luis Femando. "Pouca vergonha, muila vergonha: sexo c moralidade entre as classes trabalhadoras urbanas". In:
Campos relatou que por mais de uma vez tremera com medo dele. Diz csse autor que, quando tinha seis anos, sua mãe o amedrontava "com o monstro que trazia esse nome". Porém, na história que ela the contava, "toda entremeada de versos", Maria da Conceição não era a "criatura vil de que falavam os autos", mas "uma bonita moça, afilhada dele...". Contudo. "às portas da velhice", após ter estudado nos manuais jurídicos a "verdadeira versão dos fatos", Campos deixava de lado o que aprendera com a cultura popular $\mathrm{c}$, num mea culpa, pedia ao desembargador que o perdoasse, e a Deus que jamais pusesse em seu caminho uma Maria da Conceição (CAMPOS, 1935, p. 184).

LOPES. José Sćrgio Leite (coord.). Cullura e Identidade Operára: Aspectos da Cultura da Classe Trabalhadora. Rio de Jantiro, Marco Zero/Museu Nacional. s/d.

ENGEL. Magali. Meretrizes e Dontores: Saber Médico e Prostiruiçäo no Rio de Janeiro (1840-1890). Sío Paulo, Brasiliense. 1988.

ESTEVES. Martha de Abru. Meninas Perdidas: Os Popularese - Cotidiano do Amor no Rio de Janeino da Belle Époque. Rio de Janeiro, Paz e Terra, 1989.

FAUSTO. Boris. Crime e Contidiano: A Criminalidade em Sāo Paulo(/8so-1924). São Paulo. Brasiliense, 1984.

FERRI, Enrico. Sociologia Criminale. $5^{2}$ ediçāo. Turim. Unione Tipoghrafico - Editrice Torinense. 1929 ( I c edição francesa de (882).

FOUCAULT, Michel. Historia da Sexualidade I - A Vontade de Saber: Rio de Janciro. Graal. 1980.

LOMBroso. Cesare. L'Uomo Delinquente. $2^{2}$ edição. Turim: Livraria Boca. 1878 ( $I^{2}$ edição de 1876).

MINTZ, Sidney \& PRICE. Richard. An Anhropologycal Aproach (1) the Afru-American Past. A Caribean Perspective. Filadélfia, Instilute for Study of Human Issues, 1976.

MORAES. Antonio Evaristo de. Um Erry Judicicirio: $O$ Caso Pones Vissueiro. Rio de Janeiro. Áricl, 1934. 
NETO. Machado A. L. Histiria das Idéias Juridicas no Brasil. Stoo Paulo, Grijalbo, 1969.

OLIVEIRA, José Lopes de. Manual de Direiro de Famfilia. Reci- fe. Universidade Federal de Pernambuco, 1968.

RAGO, Margareth. Do Cabaré ao Lar - A Uiopia da Cidade Dis. ciplinar (1890-1930). Rio de Janeiro. Paz c Terra, 1985. 